\title{
Electro Chemical Honing (ECH) - A NeW Paradigm In Hybrid Machining Process
}

\author{
RAO, P.S., JAIN P.K. \& DWIVEDI D.K.
}

Abstract: Surface roughness has become the most significant functional requirement and it is an index of product quality. Nowadays, the manufacturing industries are specially focusing on dimensional accuracy and surface finish. In order to achieve the best possible surface finish as well material removal amount the advanced machining method is desirable. Hence there is a need to optimize the process parameters to achieve these responses by using design of experiment (DOE) methods. The chapter reports comparison of experimental investigations of external cylindrical surfaces of Ti alloys and EN8 steel by electrochemical honing (ECH) process. It describes the design and fabrication of an indigenously developed tooling setup and also highlights the effect of key process parameters on surface finish and MRR. It also describes the influence of machining parameters on surface finish $(R a)$ for both the materials Ti6Al4V and EN8 Steel. It compares the percentage improvements in surface roughness values PIRa, with respect to processing time.

Key words: Electro chemical honing, Ti $6 A l 4 V$ and EN8 steel, DOE; Surface finish, Material removal rate
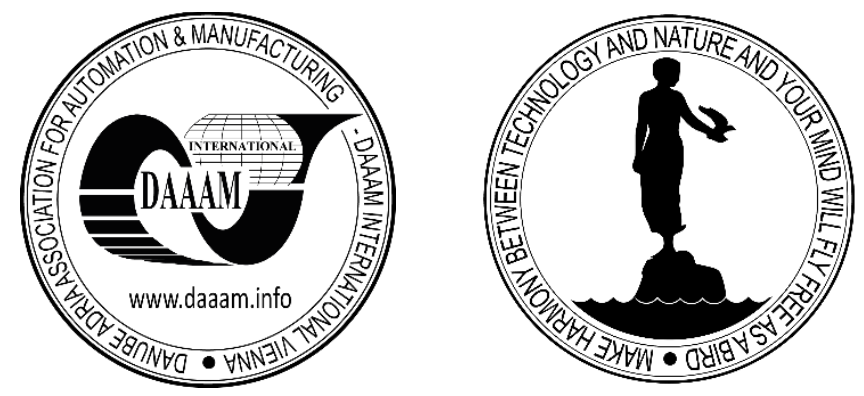

Authors' data: Research Scholar Rao, P[atange] S[udhakar]*; Prof. Jain, P[ramod] K[umar]*; Prof. Dwivedi, D[heerendra] K[umar]*; Mechanical \& Industrial Engineering Department, Indian Institute of Technology Roorkee, Roorkee, INDIA, psrao.iitr@gmail.com, psraodme@iitr.ernet.in

This Publication has to be referred as: Rao, P[.] S[udhakar]; Jain, P[.] K[.] \& Dwivedi, D[heerendra] K[umar] (2016). Electro Chemical Honing (Ech) - a New Paradigm in Hybrid Machining Process, Chapter 26 in DAAAM International Scientific Book 2016, pp.287-306, B. Katalinic (Ed.), Published by DAAAM International, ISBN 978-3-902734-09-9, ISSN 1726-9687, Vienna, Austria DOI: $10.2507 /$ daaam.scibook.2016.26 
Rao, P. S.; Jain, P. K. \& Dwivedi, D. K.: Electro Chemical Honing (Ech) - a New P...

\section{Introduction}

Electrochemical honing $(\mathrm{ECH})$ is a non-traditional micro finishing process and is the combination of two processes namely electrochemical machining (based on the faradays law of electrolysis) and mechanical honing. ECH technique is valid only for conductive materials and it is not dominance by hardness and toughness of work piece. Approximately $90 \%$ material removes during electrochemical machining and rest $10 \%$ by honing action. Metal oxide layer formed on the top of work surface during electro chemical machining (ECM), this oxide layer hampers further finishing of work piece. Honing action removes oxide layers and generate fresh surface for ECM (Benedict, 1987). After ECH one can see cross-hatch layer pattern on the work surface due to rotation and reciprocation of honing tool. Electrochemical machining without honing action reduces the current by 10 to $20 \%$ and MRR by $50 \%$ (El-Hofi, 2005) due to formation of oxide layer. ECH gives mirror surface finish of $0.05 \mu \mathrm{m}$ and tolerance \pm $0.002 \mathrm{~mm}$ (Dubey, 2008). ECH process has capabilities to correct any geometrical inexactness on cylindrical body, tapper hole and axial distortion at short duration. Honing sticks used in $\mathrm{ECH}$ process as silicon carbide ( $\mathrm{SiC})$, aluminum oxide $\left(\mathrm{Al}_{2} \mathrm{O}_{3}\right)$, Cubic Boron Nitride (CBN), diamond etc., depending on the work surface. Titanium is one of the most conductive material which is very difficult to machine by traditional as well as non-traditional machining methods.

Super finishing is one of the abrasive machining process which improves the surface finish and work piece geometry. It is generally used for removing surface irregularities, burrs, reducing surface stress and producing high wear resistance surface. While, conventional finishing process sustains some surface micro irregularities like waviness and out of roundness (El-Hofi, 2005). In order to improve the tribological properties, fatigue strength and corrosion resistance, a reasonably good surface finish is desired. With tremendous development in manufacturing technology, more and more challenging problems are faced by the engineers and researchers in the field of machining area (Chen, 1981). The rapid development in advanced industries like aerospace, automobile, nuclear power and turbine industries has been accompanied by the development of very hard, high strength, difficult-to-machine non-ferrous materials and other super alloys and the titanium is one of the most potential among them (Merchant,1961).

Other alloys such as super alloys, stainless steel, tantalum, nimonics, ceramics, composites etc. having high strength to weight ratio and low machinability are also some examples. Producing complicated geometries and maintaining high dimensional accuracy in such materials become extremely difficult with the conventional machining methods. This necessitates the exploration of Advanced Manufacturing Processes (AMPs) (Pandey and Shan, 2005). Hybrid Manufacturing Processes are conceptualized by combining either two or more than two AMPs or AMPs and conventional process to simultaneously exploit the potentials and capabilities and also to minimize the adverse effects of individual. 


\section{Titanium Alloy and EN8 Steel}

Due to the combination of low density and high strength, titanium alloys (Ti 6Al $4 \mathrm{~V}$ ) are widely used in mechanical engineering, especially in the fields of aerospace and medical engineering. Titanium alloys are extensively used in aerospace, petroleum and chemical industry due to their specific strength, fracture resistance, strong corrosion resistance and ability to retain high strength at elevated temperatures. Recently, the titanium and its alloys are also widely used as biomedical materials to act as a load bearing implant in orthopedic surgery. However, these alloys have poor machinability due to their low thermal conductivity, high chemical reactivity and low modulus of elasticity resulting in high cutting temperature and rapid tool wear $(\mathrm{Lu}$ \&Leng, 2005). During machining of titanium and its alloys by conventional processes, the above characteristics lead to high temperature at cutting interfaces. Keeping in view the severity of machining of titanium and its alloys by conventional machining processes, the need of development of newer concept for machining of titanium with hybrid process is explored (Sun et al, 2009). Among advanced machining processes, electrochemical honing $(\mathrm{ECH})$ is to be used for this purpose because of its much favorable features. In this, the material is removed at atomic scale by electrolytic dissolution and mechanical honing abrasive action (Bannard, 1976)(He, 2000). Therefore, the process can produce good surface finish and moreover, it has no damaging effect on the mechanical properties of the metal (De Burr \&Oliver, 1968). The process is particularly useful for rapid removal of metal from the surface.

EN8 steel is widely used in mechanical engineering, especially in the fields of automobile, machine building division, process industries and production workshop. The combination of various properties of EN8 leads to machine by unconventional process against other conventional processes (Das, 2014) (Mandal, 2013). ECH has the advantage of not causing thermal distortion on the machined surface. By electrochemical honing process the work piece and the tool are the anode and cathode respectively, separated by an electrolyte. When the current is passed through the electrolyte, the anode dissolves locally specularly obtaining the cathode. However, developing an ECH process for the material removal is not simple, due to generation of a passive oxide layer surface on work piece materials. This layer must be removed in a controlled manner by mechanical honing process. Electrochemical honing process is used for the machining of Ti alloys and most of the material is removed at an atomic scale by electrolytic dissolution and rest by mechanical honing abrasive action (Rao et al, 2014). As the ECH process is one of the latest and advanced one which can be used for machining of EN8 steel also because of its feasible favorable features of low cost availability (Rao et al, 2015).

\section{Electro Chemical Honing}

Electrochemical honing is a hybrid machining process combining the high material removal capability of ECM process with the controlled functional surface generating capability of conventional honing in a single operation. Electrochemical honing combines electrochemical dissolution and honing in a simultaneous action 
Rao, P. S.; Jain, P. K. \& Dwivedi, D. K.: Electro Chemical Honing (Ech) - a New P...

whereby material is removed from electrically conductive work pieces through a combination of anodic dissolution and mechanical abrasion. In this way, the fast material removal capabilities of electrochemical machining and the controlled functional surface generating capabilities of honing are combined in a single operation, providing a range of benefits to the machined surfaces not obtainable by either of the processes when applied independently (Wei, 1987). ECH can offer a unique range of benefits to the machined surface which cannot be obtained by either of the processes when applied independently (Budzynski, 1980). The ability of ECH to apply these benefits productively, has led to its widespread use in industries, especially in aerospace, automobiles, petrochemical reactor, roller and gear manufacturing industries (Misra et al, 2011) (Misra et al, 2012).

The process has the flexi-features with regard to control of machined surface characteristics in providing a surface which can have a distinct crosshatch lay pattern required for oil retention, compressive residual stresses desirable for the components subjected to cyclic loading as well as a completely stress free surface. This has made $\mathrm{ECH}$ an ideal choice for improving the surface integrity of critical components made of hard and tough materials and the parts, which are susceptible to heat distortions. The ability of ECH to apply these benefits productively, has led to its widespread use in many industries. In $\mathrm{ECH}$, generally around eighty percent, of the material removal occurs through electrolytic action. As with conventional ECM, the work piece is the anode, and a copper tool is the cathode. The electrolytic material removal is accomplished by introducing electrolyte into the gap between the tool body and the anode work piece. The honing tool strokes through the bore with the same generating motions in conventional honing [6]. The process is five to eight times faster than honing and four times faster than grinding. It can provide surface finish up to $0.05 \mu \mathrm{m}$. It provides fine surface generation by of honing and fast material removal by ECM in a single operation (Dubey, 2006) (Misra et al, 2013). The honing process is used to obtain precise dimensions and surfaces in cylindrical shapes with a wide range of diameters. The electro chemical honing process is even used to obtain precise dimensions and surfaces in cylindrical shapes with a wide range of diameters.

The honing process offers advantages of high metal removal rates, and extreme accuracy of $0.001 \mathrm{~mm}$ in a wide variety of materials. Other advantages include the ability to create round and straight bores in relatively long work pieces. Work piece bore length-to-diameter ratios of 1.5:1 and longer are ideal for the process. The abrasive action of the honing tool removes material from the work piece's outside diameter, since the tool is designed for external cylindrical surfaces. The tool rotates and reciprocates while the work piece is stationary fixed in machine chamber fixture. This rotary \& reciprocation movement is the single most important point in achieving the closer tolerances required in industry today. This process applies to parts such as Hydraulic Cylinders, Pistons, Bearing Bores, Pin Holes, Gun Barrels and to some extent External Cylindrical Surfaces. The paper describes about the surface finishing of external cylindrical surfaces of EN8 steel material by this ECH process. However, many researchers are studied different surface characteristics of EN8 steel by other advanced manufacturing processes like EDM, ECM etc to achieved better capabilities (Sunil et al, 2014). 


\section{Experimentation Details}

\subsection{Experimental setup}

Electro chemical honing process involves the electrolytic dissolution and mechanical scrubbing, the design, fabrication and material selection can achieve based on some relevant considerations such as electrical conductivity, anti-corrosiveness, electrical insulation, machinability and economic feasibility. Therefore, based on objectives of study an experimental setup for surface finishing of external cylinders has been developed for the work pieces of EN8 Steel and Titanium alloys. The application of ECH for surface finishing of external cylinders has not been given kind attention so far and as a consequence even no such experimental setup has been reported neither from the academicians nor from the industrialists. The setup consists of power supply system, electrolyte supply system, tooling system, tool motion system and machining chamber and fixtures. A schematic view of ECH tool with workpiece interaction has been shown in Fig.1. The power supply system consists of 0-100 V and 100A DC supplying unit having provision for operating at both continuous and pulsating condition. The electrolyte supply system is consisting of reservoir, pump, flow meter, pressure gauges, heat exchanger, chamber drains, magnetic filters, settling tank, etc. This subsystem is employed to provide power supply to the anodic work piece and cathode tool to complete the electric circuit. The purpose of this sub-element is to supply the filtered electrolyte with controlled flow rate and pressure to the machining zone. The entire tooling system is enclosed in a machining chamber.

Machining chamber also has provisions for supply of fresh electrolytes, for removal of used electrolyte, and for escape of gases generated during ECH process. The machining chamber is connected to the cast iron frame using four brass screws. Thus, it is attached to the machine column of bench drilling machine using a swivel arrangement for ease in loading and unloading. The swivel system can slide on the machine column to achieve axial positioning of the tool with respect to work piece. The machining chamber is made of Perspex to obtain a better visibility of the operation. Machine chamber consists of work piece fixture and ECH tool holder assembly as shown in Fig.2. The work-holding system consists of a fixture and an electrolyte chamber and is attached to the foundation with proper insulating arrangements. The fixture and the electrolyte chamber are made of stainless steel and Perspex respectively. Automatic gauging devices, such as air gauge, are often built into the ECH setup. The worktable and machine chamber fixture design considerations include corrosion resistance and strength to take over the machining torque without deforming the workpiece. 
Rao, P. S.; Jain, P. K. \& Dwivedi, D. K.: Electro Chemical Honing (Ech) - a New P...

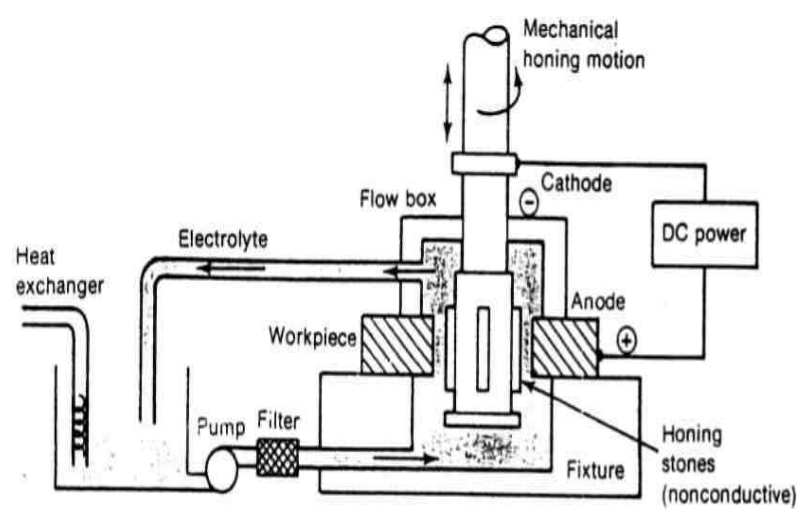

Fig. 1. Schematic view of ECH tool with work piece interaction (El Hofi, 2005)

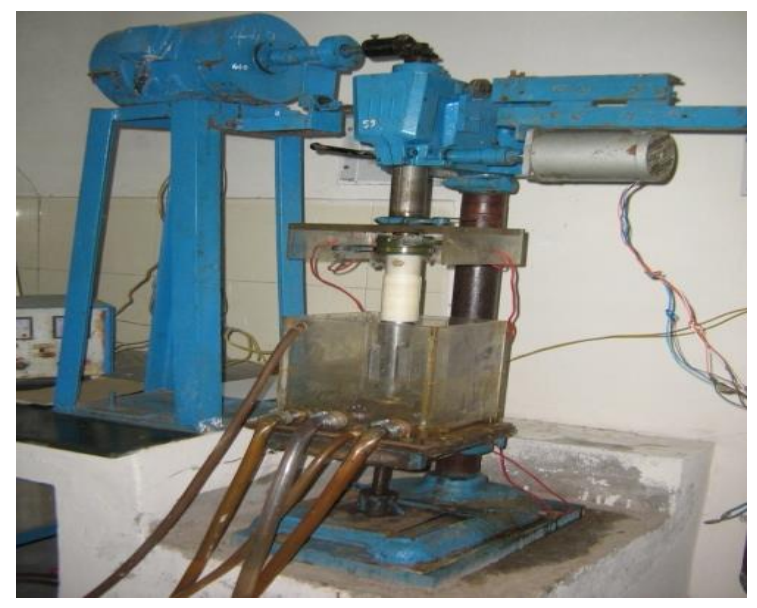

Fig. 2. Photographic view of ECH tool with assembly

The inter-electrode gap (IEG) is maintained between workpiece and the tool to avoid short circuiting, and filled with the electrolyte. During this, non-conductive spring controlled honing tool is applied with controlled pressure on the workpiece. Exploded view of ECH tool with work piece fixture is shown in Fig. 3. The honing tool is given simultaneous rotary and reciprocatory motions, as in conventional honing, to finish the workpiece surface.

The study also investigates the effects of process parameters on microstructure and surface roughness of the machined surface. The mechanism of material removal in $\mathrm{ECH}$ is based on the interaction between electrolytic actions with mechanical abrasion. The $\mathrm{SiC}$ abrasives are arranged in honing tool as shown in Fig.4. Which removes the material from the outer surface of work piece, as the tool is designed for external cylindrical surface components. The tool rotates and reciprocates while the work piece is stationary fixed in machine chamber. This rotary \& reciprocation movement of ECH tool is the single most important point in achieving the closer tolerances required and surface finish desired. 


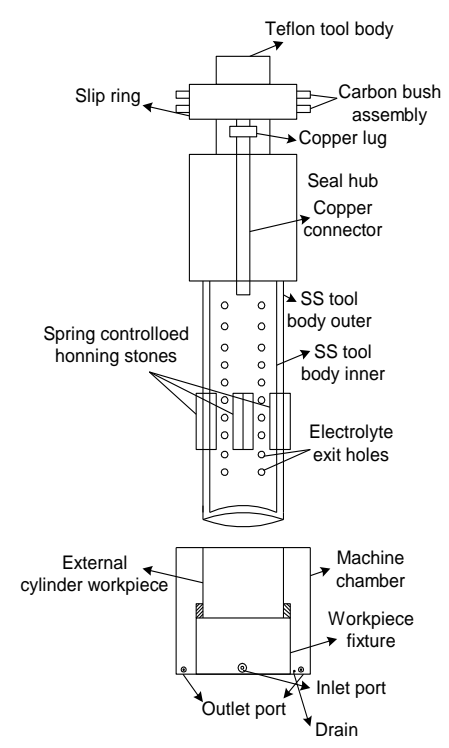

Fig. 3. Exploded view of ECH tool with work piece fixture

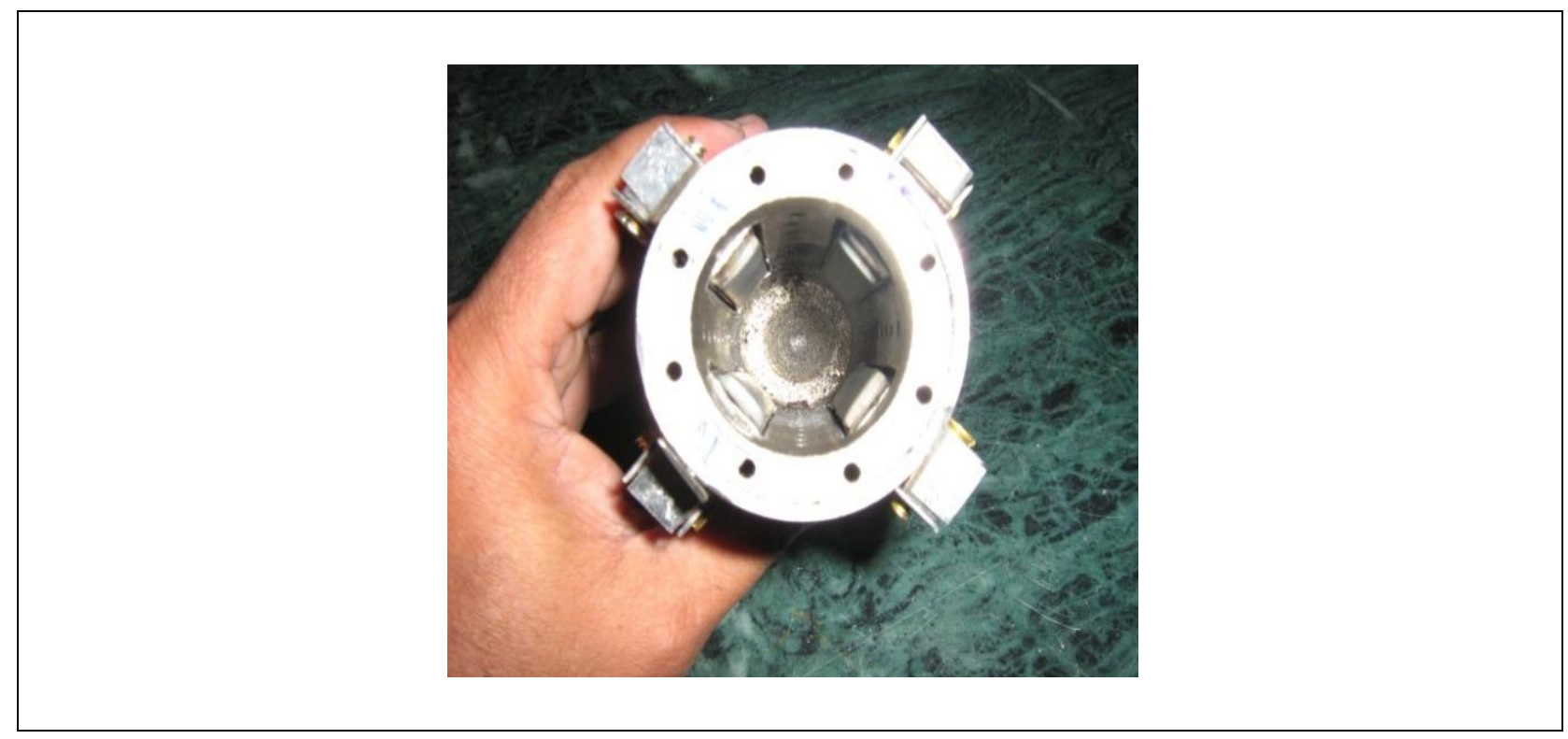

Fig. 4. Photographic view of ECH tool with honing stones

Honing stones comprise some embedded abrasive particles $\left(\mathrm{Al}_{2} \mathrm{O}_{3}, \mathrm{SiC}, \mathrm{CBN}\right)$ bonded in vitreous bonding material with particular grit size honing stones. The honing stones as shown in Fig. 5 are mounted on a stain less steel tool holder which is simultaneously given a rotary motion as well as reciprocating (or oscillatory) motion to perform a complete cycle. The rotary movement of tool can be controlled by stepper motor and while reciprocating motion can be controlled by Micro controlled based programme. The reciprocating motion is along the axis of the work piece to bring the entire work surface in contact with the honing stone. $600 \mathrm{Grit}$ size $\mathrm{SiC}$ honing stones are used to perform the experimentations for EN8 steel and Ti alloy work pieces. Selection of the abrasive type and size ( 80 to 600 mesh size) depends on the type of work piece and the rate of surface finish required as shown 
Rao, P. S.; Jain, P. K. \& Dwivedi, D. K.: Electro Chemical Honing (Ech) - a New P...

in Fig. 6. for ECM and honing operations. Honing is a finishing operation in which very small amount of material $(\approx 0.05 \mathrm{~mm})$ is removed from the work piece by means of a honing stone.

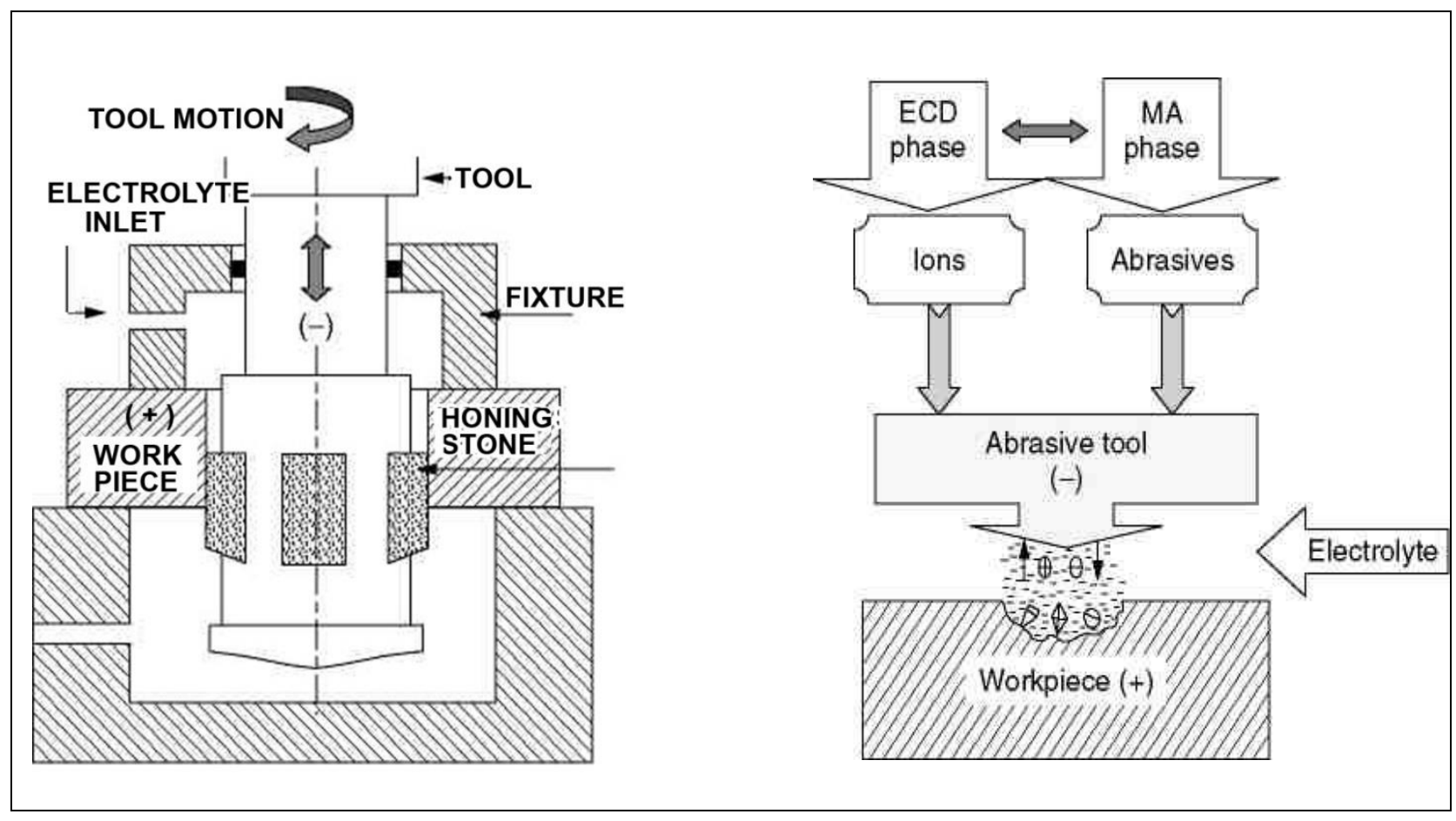

Fig. 5.Schematic view of ECH

Fig. 6. Schematic view of ECM and Honing

\subsection{Experimental procedure}

Experimental investigations were planned according to DOE technique and the experiments were conducted in different phases. In order to observe the time dependent behaviour of ECH different surface characteristics such as variation patterns of percent improvements in surface roughness values $R_{a}$ and material removal aspects were studied while changing the processing time (PT) with fully randomized one-factor at a time experimental design. The surface roughness values were measured by using optical profilometer. After determining the process parameters levels from the pilot experiments, in the next phase, experiments were designed using DOE techniques to observe the effect of key process parameters on the performance characteristics of electrochemically honed gears.

The effects of key process parameters, namely, inter electrode gap (IEG), electrolyte flow rate (EF), electrolyte pressure (EP), SiC grit size (Grit), voltage (V) and current (I) were investigated for work surface characteristics. The surface characteristics include the percentage improvement in surface roughness values of $R_{a}$, material removal and micro hardness. Results confirm the process feasibility and indicate that inter electrode gap (IEG), electrolyte flow rate (EF), electrolyte pressure (EP), SiC grit size (Grit), voltage (V) and current (I) are critical process parameters. ECH has promising capability for achieving nano finished surfaces featured with high uniformity of roughness. The present experimental studies focus on the identification 
of process performance characteristics and key input parameters. Pilot experiments were conducted to determine the ranges and levels of parameters.

Table 1 and Table 2 presents the input and fixed process parameters selected for the experimentation for Ti alloy and EN8 material respectively. The parameters and their ranges were selected on the basis of literature review, pilot experiments and machining constraints. The composition of Ti alloy and EN8 steel obtained by EDX (Energy Dispersive X-ray) were shown in Fig.7 and Fig.8. respectively. The FESEM composition of Ti alloy and EN8 were shown in Table 3 and Table 4 respectively. The surface roughness characteristics (i.e. Ra), micro-hardness and surface integrity aspects were also examined. The surface roughness parameters were measured by Wyko NT 1100 optical profilometer. The percentage improvements in surface roughness values were also calculated to visualize the improvement in the surface quality of Ti alloy and EN8 Steel. Pre-experiment and post-experiment measurements of process performance characteristics were examined using the suitable measuring instrument like Scanning Electron Microscopy (SEM) and Atomic Force Microscopy (AFM) for electro chemically honed external cylinders of Ti alloy and EN8 Steel.
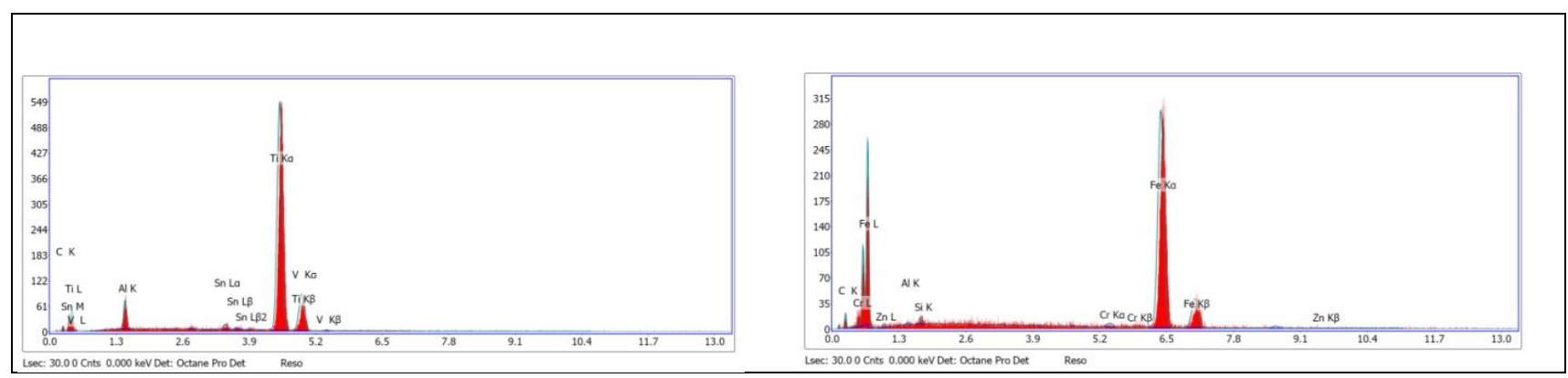

Fig. 7. Ti 6Al 4V Composition data by EDX Fig. 8. EN8 Composition data by EDX

\begin{tabular}{|c|c|}
\hline Parameters & Values \\
\hline Type of power supply & Continuous DC \\
\hline Electrolyte temperature & $30^{\circ} \mathrm{C}$ \\
\hline Processing time & $08 \mathrm{~min}$ \\
\hline Electrolyte composition & Single NaCl Soln or $\mathrm{NaNO}_{3}$ Soln \\
\hline Rotating speed & $60 \mathrm{rpm}$ \\
\hline Electrolyte concentration & $15 \% \mathrm{NaCl}$ or $10 \% \mathrm{NaNO}_{3}$ \\
\hline Honing stone & $\mathrm{SiC}$ \\
\hline
\end{tabular}

Tab. 1. Values of input and fixed parameters for experimentation of Ti alloy.

\begin{tabular}{|c|c|}
\hline Parameters & Values \\
\hline Type of power supply & Continuous DC \\
\hline Electrolyte temperature & $35^{0} \mathrm{C}$ \\
\hline Processing time & $12 \mathrm{~min}$ \\
\hline Electrolyte composition & $3 / 4 \mathrm{NaCl} \mathrm{Soln}+1 / 4 \mathrm{NaNO}_{3}$ Soln \\
\hline Rotating speed & $60 \mathrm{rpm}$ \\
\hline Electrolyte concentration & $10 \%$ \\
\hline Honing stone & $\mathrm{SiC}$ \\
\hline
\end{tabular}

Tab. 2. Values of input and fixed parameters for experimentation of EN8 Material. 
Rao, P. S.; Jain, P. K. \& Dwivedi, D. K.: Electro Chemical Honing (Ech) - a New P...

\begin{tabular}{|c|c|c|c|}
\hline $\mathbf{A l}$ & $\mathbf{V}$ & $\mathbf{T i}$ & $\mathbf{S n}$ \\
\hline $5.0-6.0 \%$ & $3.0-4.0 \%$ & $85.0-90.0 \%$ & $0.50-0.90 \%$ \\
\hline
\end{tabular}

Tab. 3. Ti alloy Ti 6Al4V Composition data by EDX.

\begin{tabular}{|c|c|c|c|c|}
\hline $\mathbf{C}$ & $\mathbf{S i}$ & $\mathbf{M n}$ & $\mathbf{S}$ & $\mathbf{F e}$ \\
\hline $0.35-0.45 \%$ & $0.05-0.35 \%$ & $0.6-1.0 \%$ & $0.06-0.10 \%$ & $80.50-90.00 \%$ \\
\hline
\end{tabular}

Tab. 4. EN8 Material Composition data by EDX.

\section{Results and Discussion}

\subsection{Experimental results of external cylindrical surfaces of Titanium alloys}

For different processing time of $\mathrm{ECH}$, surface roughness values were noted for Titanium alloys after each experimentation. Table 5 to 10 presents the surface roughness (Ra) value, of work piece before and after machining for each experimental run. The calculated percentage improvement in surface roughness values (PIRa) are also shown. The initial and final $R_{a}$ values and the percentage improvement in surface roughness $\left(\mathrm{PIR}_{\mathrm{a}}\right)$ values both are presented in Table 5,6,7,8,9 and 10 for different inter electrode gaps, electrolyte flow rate, electrolyte pressure, grit size of $\mathrm{SiC}$ abrasive, voltage and current respectively. A higher value of PIR $\mathrm{a}$ represents lower value of final average surface roughness. Percentage improvement in average surface roughness value $\left(\mathrm{PIR}_{\mathrm{a}}\right)$ is used as process response. A higher value in $\mathrm{PIR}_{\mathrm{a}}$ indicates better surface finish of work-surface and this helps to study the material removal, finished surface characteristics, and surface integrity aspects of $\mathrm{ECH}$ process.

Fig.9. Shows Average surface roughness of 3D interactive image for ECHed Ti alloy workpiece material captured by $3 \mathrm{D}$ profilometer. If average surface roughness values concerned, Fig.10. and Fig.11. Shows 2D Average surface roughness Bearimg ratio by AFM technique andAverage surface roughness Bearing ratio respectively.SEM images of the cut surfaces have revealed that the fine surface finish was obtained when machining was done at a combination of lower levels of input process parameters. When machining was done at combination of higher levels of input process parameters, some burrs arise on the machined surface.

\begin{tabular}{|c|c|c|c|c|c|c|c|c|c|}
\hline \multirow{2}{*}{$\begin{array}{c}\text { IEG } \\
\text { in } \\
\text { um }\end{array}$} & \multicolumn{3}{|c|}{$\begin{array}{c}\text { Top portion of } \\
\text { cylindrical w/p }\end{array}$} & \multicolumn{3}{c|}{$\begin{array}{c}\text { Middle portion of } \\
\text { cylindrical w/p }\end{array}$} & \multicolumn{3}{c|}{$\begin{array}{c}\text { Bottom portion of } \\
\text { cylindrical w/p }\end{array}$} \\
\cline { 2 - 11 } & $\begin{array}{c}\text { Before } \\
\text { ECH }\end{array}$ & Efter & PIR $_{\mathrm{a}}$ & Before & After & PIR & Before & After & PIR $_{\mathrm{a}}$ \\
& & ECH & ECH & & ECH & ECH & \\
\hline 1.00 & 1.58 & 0.630 & 60.12 & 1.46 & 0.660 & 54.72 & 1.59 & 0.615 & 61.32 \\
\hline 0.75 & 1.65 & 0.640 & 63.03 & 1.54 & 0.412 & 73.25 & 1.46 & 0.510 & 64.83 \\
\hline 0.50 & 1.42 & 0.301 & 78.80 & 1.50 & 0.314 & 79.01 & 1.41 & 0.304 & 75.44 \\
\hline 0.25 & 1.58 & 0.410 & 74.05 & 1.56 & 0.410 & 73.32 & 1.58 & 0.418 & 74.25 \\
\hline
\end{tabular}

Tab. 5. Average surface roughness and percentage of improvement in average surface roughness values at different inter electrode gaps, IEG. 


\begin{tabular}{|c|c|c|c|c|c|c|c|c|c|}
\hline \multirow{2}{*}{$\begin{array}{l}\text { Electrolyte } \\
\text { Flow rate } \\
\text { in lit/min }\end{array}$} & \multicolumn{3}{|c|}{$\begin{array}{l}\text { Top portion of } \\
\text { cylindrical w/p }\end{array}$} & \multicolumn{3}{|c|}{$\begin{array}{l}\text { Middle portion of } \\
\text { cylindrical w/p }\end{array}$} & \multicolumn{3}{|c|}{$\begin{array}{l}\text { Bottom portion of } \\
\text { cylindrical w/p }\end{array}$} \\
\hline & $\begin{array}{c}\text { Before } \\
\text { ECH }\end{array}$ & $\begin{array}{l}\text { After } \\
\text { ECH }\end{array}$ & $\mathrm{PIR}_{\mathrm{a}}$ & $\begin{array}{c}\text { Before } \\
\text { ECH }\end{array}$ & $\begin{array}{l}\text { After } \\
\text { ECH }\end{array}$ & $\mathrm{PIR}_{\mathrm{a}}$ & $\begin{array}{c}\text { Before } \\
\text { ECH }\end{array}$ & $\begin{array}{l}\text { After } \\
\text { ECH }\end{array}$ & $\mathrm{PIR}_{\mathrm{a}}$ \\
\hline 20 & 1.58 & 0.410 & 74.05 & 20 & 1.58 & 0.410 & 74.05 & 20 & 1.58 \\
\hline 25 & 1.46 & 0.314 & 78.49 & 25 & 1.46 & 0.314 & 78.49 & 25 & 1.46 \\
\hline 30 & 1.52 & 0.209 & 86.91 & 30 & 1.52 & 0.209 & 86.91 & 30 & 1.52 \\
\hline 35 & 1.41 & 0.320 & 77.30 & 35 & 1.41 & 0.320 & 77.30 & 35 & 1.41 \\
\hline
\end{tabular}

Tab. 6. Average surface roughness and percentage of improvement in average surface roughness values at different flow rate.

\begin{tabular}{|c|c|c|c|c|c|c|c|c|c|}
\hline \multirow{2}{*}{$\begin{array}{c}\text { Electrolyt } \\
\text { e Pressure } \\
\text { in MPa }\end{array}$} & \multicolumn{3}{|c|}{$\begin{array}{c}\text { Top portion of } \\
\text { cylindrical w/p }\end{array}$} & \multicolumn{3}{c|}{$\begin{array}{c}\text { Middle portion of } \\
\text { cylindrical w/p }\end{array}$} & \multicolumn{2}{c|}{$\begin{array}{c}\text { Bottom portion of } \\
\text { cylindrical w/p }\end{array}$} \\
\cline { 2 - 11 } & $\begin{array}{c}\text { Befor } \\
\text { e }\end{array}$ & $\begin{array}{c}\text { After } \\
\text { ECH }\end{array}$ & PIR $_{\mathrm{a}}$ & $\begin{array}{c}\text { Befor } \\
\text { e }\end{array}$ & $\begin{array}{c}\text { After } \\
\text { ECH }\end{array}$ & $\begin{array}{c}\text { PIR } \\
\text { a }\end{array}$ & $\begin{array}{c}\text { Befor } \\
\text { e }\end{array}$ & $\begin{array}{c}\text { After } \\
\text { ECH }\end{array}$ & PIR $_{a}$ \\
& & & & & ECH & & \\
\hline 0.5 & 1.61 & 0.62 & 61.4 & 1.69 & 0.61 & 63.9 & 1.58 & 0.63 & 60.1 \\
& & 9 & & 0 & 0 & & 0 & 2 \\
\hline 1.0 & 1.58 & 0.41 & 74.2 & 1.41 & 0.30 & 75.4 & 1.58 & 0.41 & 74.0 \\
& & 8 & 5 & & 4 & 4 & & 0 & 5 \\
\hline 1.5 & 1.46 & 0.51 & 64.8 & 1.52 & 0.52 & 65.7 & 1.65 & 0.64 & 63.0 \\
& & 0 & 3 & & 0 & 9 & & 0 & 3 \\
\hline 2.0 & 1.59 & 0.61 & 61.3 & 1.45 & 0.65 & 55.4 & 1.46 & 0.66 & 54.7 \\
& & 5 & 2 & & 0 & 8 & & 0 & 2 \\
\hline
\end{tabular}

Tab. 7. Average surface roughness and percentage of improvement in average surface roughness values at different flow pressure.

\begin{tabular}{|c|c|c|c|c|c|c|c|c|c|}
\hline \multirow{2}{*}{$\begin{array}{l}\mathrm{SiC} \\
\text { Grit } \\
\text { Size }\end{array}$} & \multicolumn{3}{|c|}{$\begin{array}{l}\text { Top portion of } \\
\text { cylindrical w/p }\end{array}$} & \multicolumn{3}{|c|}{$\begin{array}{c}\text { Middle portion of } \\
\text { cylindrical w/p }\end{array}$} & \multicolumn{3}{|c|}{$\begin{array}{c}\text { Bottom portion of } \\
\text { cylindrical w/p }\end{array}$} \\
\hline & $\begin{array}{c}\text { Before } \\
\text { ECH }\end{array}$ & $\begin{array}{l}\text { After } \\
\text { ECH }\end{array}$ & $\mathrm{PIR}_{\mathrm{a}}$ & $\begin{array}{c}\text { Before } \\
\text { ECH }\end{array}$ & $\begin{array}{l}\text { After } \\
\text { ECH }\end{array}$ & $\mathrm{PIR}_{\mathrm{a}}$ & $\begin{array}{c}\text { Before } \\
\text { ECH }\end{array}$ & $\begin{array}{l}\text { After } \\
\text { ECH }\end{array}$ & $\mathrm{PIR}_{\mathrm{a}}$ \\
\hline 120 & 1.52 & 0.520 & 65.79 & 1.52 & 0.520 & 65.79 & 1.65 & 0.640 & 63.03 \\
\hline 360 & 1.54 & 0.412 & 73.25 & 1.41 & 0.320 & 77.30 & 1.58 & 0.410 & 74.05 \\
\hline 600 & 1.50 & 0.315 & 79.00 & 1.46 & 0.314 & 78.49 & 1.52 & 0.315 & 79.28 \\
\hline 1200 & 1.56 & 0.410 & 73.32 & 1.58 & 0.418 & 74.25 & 1.41 & 0.304 & 75.44 \\
\hline
\end{tabular}

Tab. 8. Average surface roughness and percentage of improvement in average surface roughness values at different grit size.

\begin{tabular}{|c|c|c|c|c|c|c|c|c|c|}
\hline \multirow{2}{*}{$\begin{array}{c}\text { Current } \\
\text { in } A\end{array}$} & \multicolumn{3}{|c|}{$\begin{array}{l}\text { Top portion of } \\
\text { cylindrical w/p }\end{array}$} & \multicolumn{3}{|c|}{$\begin{array}{c}\text { Middle portion of } \\
\text { cylindrical w/p }\end{array}$} & \multicolumn{3}{|c|}{$\begin{array}{c}\text { Bottom portion of } \\
\text { cylindrical w/p }\end{array}$} \\
\hline & $\begin{array}{c}\text { Before } \\
\text { ECH }\end{array}$ & $\begin{array}{l}\text { After } \\
\text { ECH }\end{array}$ & $\mathrm{PIR}_{\mathrm{a}}$ & $\begin{array}{c}\text { Before } \\
\text { ECH }\end{array}$ & $\begin{array}{l}\text { After } \\
\text { ECH }\end{array}$ & $\mathrm{PIR}_{\mathrm{a}}$ & $\begin{array}{c}\text { Before } \\
\text { ECH }\end{array}$ & $\begin{array}{l}\text { After } \\
\text { ECH }\end{array}$ & $\mathrm{PIR}_{\mathrm{a}}$ \\
\hline 50 & 1.61 & 0.620 & 61.49 & 50 & 1.61 & 0.620 & 61.49 & 50 & 1.61 \\
\hline 60 & 1.54 & 0.412 & 73.25 & 60 & 1.54 & 0.412 & 73.25 & 60 & 1.54 \\
\hline 70 & 1.52 & 0.315 & 79.28 & 70 & 1.52 & 0.315 & 79.28 & 70 & 1.52 \\
\hline 80 & 1.41 & 0.304 & 75.44 & 1.50 & 0.315 & 79.00 & 1.46 & 0.314 & 78.49 \\
\hline
\end{tabular}

Tab. 9. Average surface roughness and percentage of improvement in average surface roughness values at different current ratings. 
Rao, P. S.; Jain, P. K. \& Dwivedi, D. K.: Electro Chemical Honing (Ech) - a New P...

\begin{tabular}{|c|c|c|c|c|c|c|c|c|c|}
\hline \multirow{2}{*}{$\begin{array}{l}\text { Voltage } \\
\text { In V }\end{array}$} & \multicolumn{3}{|c|}{$\begin{array}{l}\text { Top portion of } \\
\text { cylindrical w/p }\end{array}$} & \multicolumn{3}{|c|}{$\begin{array}{l}\text { Middle portion of } \\
\text { cylindrical w/p }\end{array}$} & \multicolumn{3}{|c|}{$\begin{array}{l}\text { Bottom portion of } \\
\text { cylindrical w/p }\end{array}$} \\
\hline & $\begin{array}{l}\text { Before } \\
\text { ECH }\end{array}$ & $\begin{array}{l}\text { After } \\
\text { ECH }\end{array}$ & $\mathrm{PIR}_{\mathrm{a}}$ & $\begin{array}{c}\text { Before } \\
\text { ECH }\end{array}$ & $\begin{array}{l}\text { After } \\
\text { ECH }\end{array}$ & $\mathrm{PIR}_{\mathrm{a}}$ & $\begin{array}{c}\text { Before } \\
\text { ECH }\end{array}$ & $\begin{array}{l}\text { After } \\
\text { ECH }\end{array}$ & $\mathrm{PIR}_{\mathrm{a}}$ \\
\hline 10 & 1.46 & & & 1.69 & & & 1.5 & & \\
\hline & & & & & & & 1.4 & & 55.48 \\
\hline 30 & & & 65.79 & 1.46 & 0.5 & 64. & 1.65 & & 63.03 \\
\hline 40 & 1.58 & 0.630 & 60.12 & 1.80 & 0.810 & 55.00 & 1.46 & 0.660 & 54.32 \\
\hline
\end{tabular}

Tab. 10. Average surface roughness and percentage of improvement in average surface roughness values at different voltage ratings.

\subsection{Experimental results and data figures of Titanium Alloy Ti $6 \mathrm{Al} 4 \mathrm{~V}$}

Micro-structure study and Micro-structure characterization have been carried out to investigate the impact ofthe process on surface integrity aspects of the machined surface.Fig.12. and Fig.13 Shows Average surface roughness Histogram data and 2D Average surface roughness Histogram data AFM technique respectively. As the ECH process is feasible for better material removal and shiny finishing look. It is evident from the plots that the surface roughness present in the surface after ECH is significantly reduced by this process.

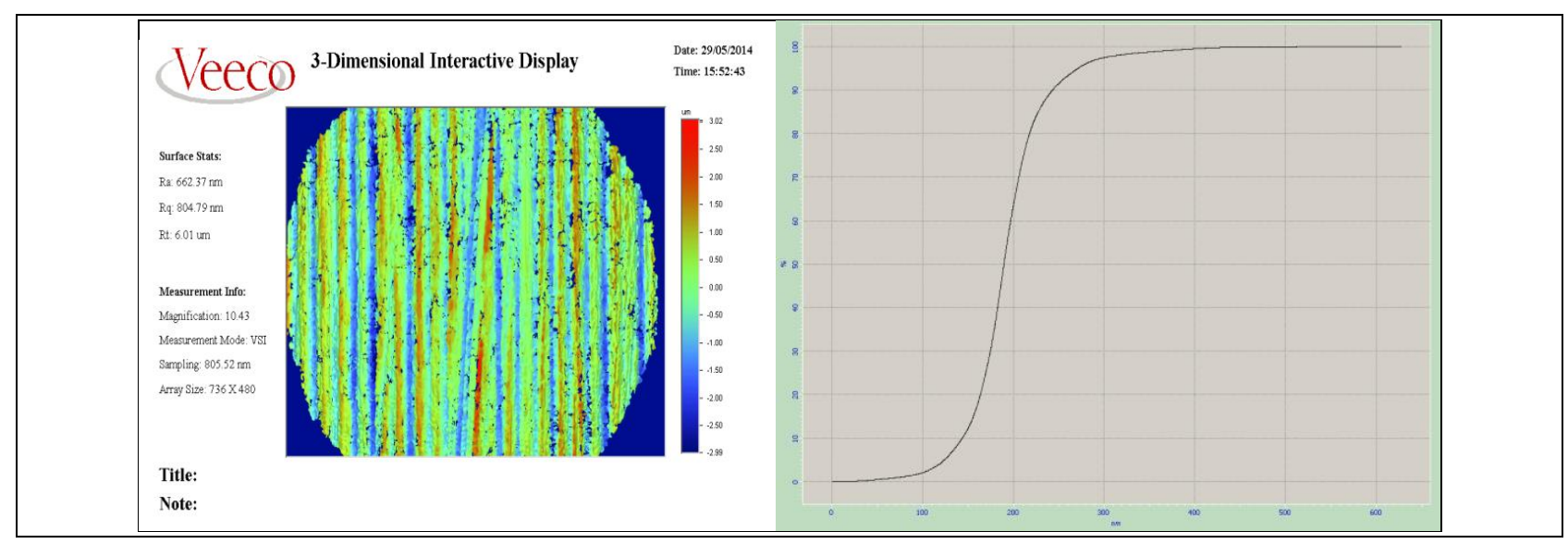

Fig. 9. 3D Average surface roughness data Fig. 10. 2D Bearing ratio data of Ti alloy by AFM

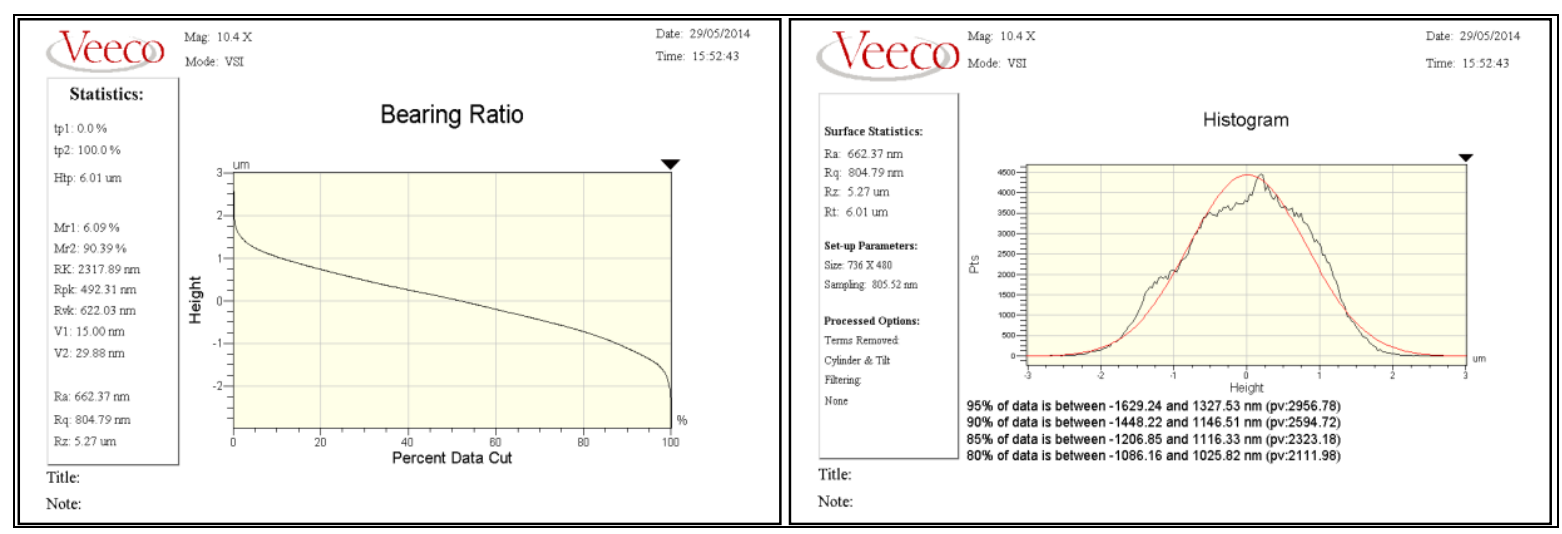

Fig. 11. Bearing ratio data of Ti alloy Fig.12. Histogram data of Ti alloy Ti6A14V 
The experimental results describes that, a very good improvement in average surface roughness $\mathrm{Ra}$ about $78.80 \%$ at top portion of the Cylindrical work piece, $79.09 \%$ at middle portion of the Cylindrical work piece and $75.44 \%$ at bottom portion of the Cylindrical work piece at $0.50 \mu$ minter electrode gap for the processing time of 08 minutes of Finishing Time as shown in Table 5. If an electrolyte flow rate is concerned, Table 6 results reveals that better surface finish at maximum 30lit/min of electrolyte flow rate and shows a very good percentage improvement in surface finish about $86.91 \%$ at top portion of the Cylindrical work piece, $85.76 \%$ at middle portion of the Cylindrical work piece and $85.95 \%$ at bottom portion of the Cylindrical work piece respectively. From the results of electrolyte pressure is concerned, the Table 7 describes that, $1 \mathrm{MPa}$ of electrolyte pressure gives better surface finish and shows a very good percentage improvement in surface finish about $74.25 \%$ at top portion of the Cylindrical work piece, $75.44 \%$ at middle portion of the Cylindrical work piece and $74.05 \%$ at bottom portion of the Cylindrical work piece respectively at $1 \mathrm{MPa}$ of electrolyte pressure.

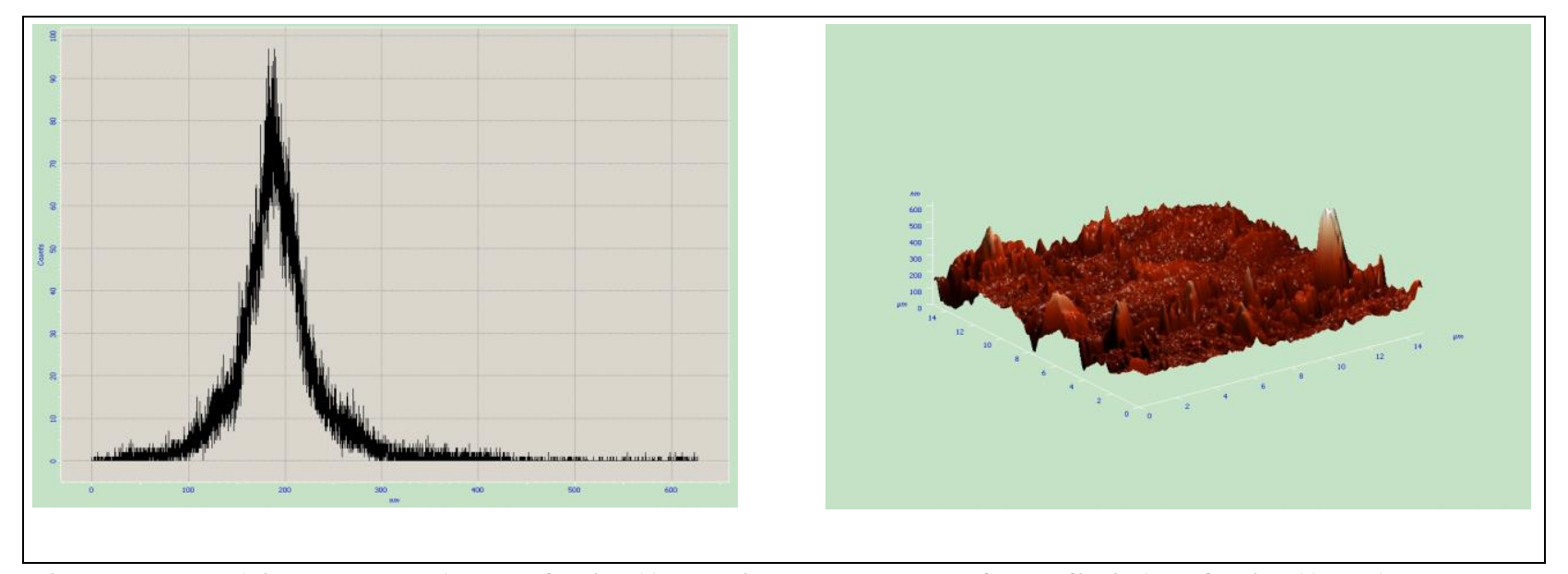

Fig. 13. 2D histogram data of Ti alloy Fig.14. 3D surface finish of Ti alloy by AFM

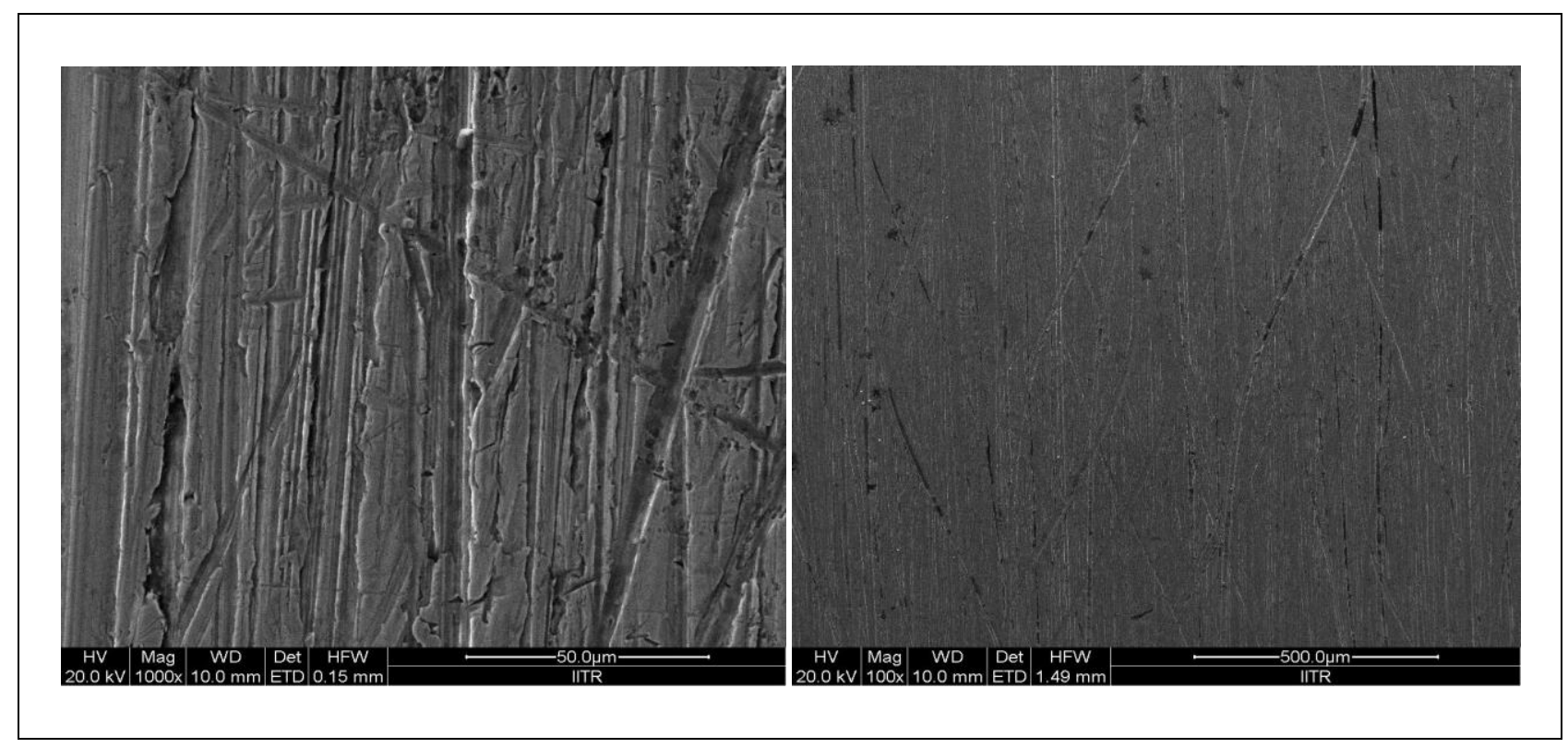

(a)

(b) 
Rao, P. S.; Jain, P. K. \& Dwivedi, D. K.: Electro Chemical Honing (Ech) - a New P...

Fig.15. SEM photographs of electrochemically honed (ECHed) Ti alloy Ti6Al4V surface (a) before ECH and (b) after ECH

Fig.14. shows 3D surface roughness of Ti alloy Ti 6Al 4V by AFM technique and there is considerable decrease in surface roughness with increase in processing time. If grit size of $\mathrm{SiC}$ abrasive is concerned, from the Table 8 it is evident that, 600 grit size of $\mathrm{SiC}$ abrasive gives better surface finish and shows a very good percentage improvement in surface finish about $79.00 \%$ at top portion of the Cylindrical work piece, $78.49 \%$ at middle portion of the Cylindrical work piece and $79.23 \%$ at bottom portion of the Cylindrical work piece respectively at 600 grit size of SiC. Fig.15. shows SEM photographs of electrochemically honed (ECHed) Ti alloy work piece surface (a) before $\mathrm{ECH}$ and (b) after ECH.

From the experimental results, it can be observed that a very good improvement in average surface roughness Ra about $79.28 \%$ at top portion of the Cylindrical work piece, $85.95 \%$ at middle portion of the Cylindrical work piece and $86.91 \%$ at bottom portion of the Cylindrical work piece at 70 amperes of current as shown in Table 9. From the results of voltage is concerned, the Table 10 describes that, 30 volts of voltage gives better surface finish and shows a very good percentage improvement in surface finish about $65.79 \%$ at top portion of the Cylindrical work piece, $64.83 \%$ at middle portion of the Cylindrical work piece and $63.03 \%$ at bottom portion of the Cylindrical work piece respectively.

\subsection{Experimental results of external cylindrical surfaces of EN8 material}

The surface roughness values obtained for EN8 material were noted for different processing time. Table 11 to Table16 presents the surface roughness (Ra) value, of work piece before and after machining for each experimental run. The calculated percentage improvement in surface roughness values (PIRa) are also shown. The initial and final $R_{a}$ values and the percentage improvement in surface roughness values both are presented in Table 11,12,13,14,15 and 16 for different inter electrode gaps, electrolyte flow rate, electrolyte pressure, grit size of $\mathrm{SiC}$ abrasive, current and voltage respectively. A higher value of PIR $_{a}$ represents lower value of final average surface roughness. Percentage improvement in average surface roughness value PIR $_{a}$ is used as process response and this helps to study the material removal, finished surface characteristics, and surface integrity aspects of ECH process. A higher value in PIR indicates better surface finish of work-surface.

Fig. 16. Shows Average surface roughness of 3D interactive image for ECHed EN8 alloy workpiece material captured by 3D profilometer. Micro-structure study and Micro-structure characterization have been carried out to investigate the impact ofthe process on surface integrity aspects of the machined surface. SEM images of the cut surfaces have revealed that the fine surface finish was obtained when machining was done at a combination of lower levels of input process parameters. Fig. 17. and Fig. 18. Shows 2D Average surface roughness Bearimg ratio by AFM technique andAverage surface roughness Bearing ratio respectively. 


\begin{tabular}{|c|c|c|c|c|c|c|c|c|c|}
\hline \multirow{2}{*}{$\begin{array}{c}\text { IEG } \\
\text { In } \\
\text { um }\end{array}$} & \multicolumn{3}{|c|}{$\begin{array}{l}\text { Top portion of } \\
\text { cylindrical w/p }\end{array}$} & \multicolumn{3}{|c|}{$\begin{array}{l}\text { Middle portion of } \\
\text { cylindrical w/p }\end{array}$} & \multicolumn{3}{|c|}{$\begin{array}{l}\text { Bottom portion of } \\
\text { cylindrical w/p }\end{array}$} \\
\hline & $\begin{array}{c}\text { Before } \\
\text { ECH }\end{array}$ & $\begin{array}{l}\text { After } \\
\text { ECH }\end{array}$ & $\mathrm{PIR}_{\mathrm{a}}$ & $\begin{array}{c}\text { Before } \\
\text { ECH }\end{array}$ & $\begin{array}{l}\text { After } \\
\text { ECH }\end{array}$ & $\mathrm{PIR}_{\mathrm{a}}$ & $\begin{array}{c}\text { Before } \\
\text { ECH }\end{array}$ & $\begin{array}{l}\text { After } \\
\text { ECH }\end{array}$ & $\mathrm{PIR}_{\mathrm{a}}$ \\
\hline 1.00 & 4.20 & & 75.08 & 4.16 & & 76.44 & 4.06 & & 77.83 \\
\hline 0.75 & 4.18 & 0.900 & 78.47 & 4.08 & 0.9 & 77.42 & 4.38 & 0.8 & 79.68 \\
\hline 0.50 & 4.90 & 0.9 & 80.63 & 4.89 & 0.950 & 80.57 & 4.46 & 07 & 84.08 \\
\hline 0.25 & 4.21 & 1.050 & 75.06 & 4.17 & 0.990 & 76.26 & 4.18 & 0.979 & 76.58 \\
\hline
\end{tabular}

Tab. 11. Average surface roughness and percentage of improvement in average surface roughness values at different inter electrode gaps,IEG.

\begin{tabular}{|c|c|c|c|c|c|c|c|c|c|}
\hline \multirow{2}{*}{$\begin{array}{l}\text { Electrolyt } \\
\text { e Flow } \\
\text { rate } \\
\text { In lit/min }\end{array}$} & \multicolumn{3}{|c|}{$\begin{array}{l}\text { Top portion of } \\
\text { cylindrical w/p }\end{array}$} & \multicolumn{3}{|c|}{$\begin{array}{l}\text { Middle portion of } \\
\text { cylindrical w/p }\end{array}$} & \multicolumn{3}{|c|}{$\begin{array}{l}\text { Bottom portion of } \\
\text { cylindrical w/p }\end{array}$} \\
\hline & $\begin{array}{l}\text { Befor } \\
\text { e } \\
\text { ECH }\end{array}$ & $\begin{array}{l}\text { After } \\
\text { ECH }\end{array}$ & $\mathrm{PIR}_{\mathrm{a}}$ & $\begin{array}{l}\text { Befor } \\
\text { e } \\
\text { ECH }\end{array}$ & $\begin{array}{l}\text { After } \\
\text { ECH }\end{array}$ & $\mathrm{PIR}_{\mathrm{a}}$ & $\begin{array}{l}\text { Befor } \\
\text { e } \\
\text { ECH }\end{array}$ & $\begin{array}{l}\text { After } \\
\text { ECH }\end{array}$ & $\mathrm{PIR}_{\mathrm{a}}$ \\
\hline 20 & 4.30 & $\begin{array}{c}0.91 \\
0\end{array}$ & $\begin{array}{c}78.8 \\
3\end{array}$ & 4.39 & $\begin{array}{c}0.90 \\
0\end{array}$ & $\begin{array}{c}79.5 \\
0\end{array}$ & 5.65 & $\begin{array}{c}1.20 \\
0\end{array}$ & $\begin{array}{c}78.7 \\
6\end{array}$ \\
\hline 25 & 4.10 & $\begin{array}{c}0.80 \\
5\end{array}$ & $\begin{array}{c}80.7 \\
5\end{array}$ & 4.60 & $\begin{array}{c}0.81 \\
4\end{array}$ & $\begin{array}{c}82.3 \\
0\end{array}$ & 5.60 & $\begin{array}{c}0.98 \\
0\end{array}$ & $\begin{array}{c}80.3 \\
6\end{array}$ \\
\hline 30 & 4.18 & $\begin{array}{c}0.97 \\
9\end{array}$ & $\begin{array}{c}76.5 \\
8\end{array}$ & 4.20 & $\begin{array}{c}1.04 \\
9\end{array}$ & $\begin{array}{c}75.0 \\
8\end{array}$ & 4.19 & $\begin{array}{c}0.91 \\
5\end{array}$ & $\begin{array}{c}78.4 \\
0\end{array}$ \\
\hline 35 & 4.21 & $\begin{array}{c}1.05 \\
0\end{array}$ & $\begin{array}{c}75.0 \\
6\end{array}$ & 4.21 & $\begin{array}{c}1.05 \\
0\end{array}$ & $\begin{array}{c}75.0 \\
6\end{array}$ & 4.16 & $\begin{array}{c}0.98 \\
0\end{array}$ & $\begin{array}{c}76.4 \\
4\end{array}$ \\
\hline
\end{tabular}

Tab. 12. Average surface roughness and percentage of improvement in average surface roughness values at different flow rate.

\begin{tabular}{|c|c|c|c|c|c|c|c|c|c|}
\hline \multirow{2}{*}{$\begin{array}{c}\text { Electrolyt } \\
\text { e Pressure } \\
\text { in MPa }\end{array}$} & \multicolumn{3}{|c|}{$\begin{array}{l}\text { Top portion of } \\
\text { cylindrical w/p }\end{array}$} & \multicolumn{3}{|c|}{$\begin{array}{l}\text { Middle portion of } \\
\text { cylindrical w/p }\end{array}$} & \multicolumn{3}{|c|}{$\begin{array}{l}\text { Bottom portion of } \\
\text { cylindrical w/p }\end{array}$} \\
\hline & $\begin{array}{l}\text { Befor } \\
\text { e } \\
\text { ECH }\end{array}$ & $\begin{array}{l}\text { After } \\
\text { ECH }\end{array}$ & $\mathrm{PIR}_{\mathrm{a}}$ & $\begin{array}{l}\text { Befor } \\
\text { e } \\
\text { ECH }\end{array}$ & $\begin{array}{l}\text { After } \\
\text { ECH }\end{array}$ & $\mathrm{PIR}_{\mathrm{a}}$ & $\begin{array}{l}\text { Befor } \\
\text { e } \\
\text { ECH }\end{array}$ & $\begin{array}{l}\text { After } \\
\text { ECH }\end{array}$ & $\mathrm{PIR}_{\mathrm{a}}$ \\
\hline 0.5 & 4.21 & $\begin{array}{c}1.05 \\
0\end{array}$ & $\begin{array}{c}75.0 \\
6\end{array}$ & 4.06 & $\begin{array}{c}0.90 \\
1\end{array}$ & $\begin{array}{c}77.8 \\
3\end{array}$ & 4.16 & $\begin{array}{c}0.98 \\
0\end{array}$ & $\begin{array}{c}76.4 \\
4\end{array}$ \\
\hline 1.0 & 4.20 & $\begin{array}{c}1.04 \\
9\end{array}$ & $\begin{array}{c}75.0 \\
8\end{array}$ & 4.19 & $\begin{array}{c}0.91 \\
5\end{array}$ & $\begin{array}{c}78.4 \\
0\end{array}$ & 4.18 & $\begin{array}{c}0.97 \\
9\end{array}$ & $\begin{array}{c}76.5 \\
8\end{array}$ \\
\hline 1.5 & 4.45 & $\begin{array}{c}0.71 \\
0\end{array}$ & $\begin{array}{c}84.0 \\
4\end{array}$ & 4.55 & $\begin{array}{c}0.85 \\
4\end{array}$ & $\begin{array}{c}87.2 \\
3\end{array}$ & 4.89 & $\begin{array}{c}0.95 \\
0\end{array}$ & $\begin{array}{c}80.5 \\
7\end{array}$ \\
\hline 2.0 & 4.90 & $\begin{array}{c}0.94 \\
9\end{array}$ & $\begin{array}{c}80.6 \\
3\end{array}$ & 4.10 & $\begin{array}{c}0.80 \\
5\end{array}$ & $\begin{array}{c}80.7 \\
5\end{array}$ & 4.30 & $\begin{array}{c}0.91 \\
0\end{array}$ & $\begin{array}{c}78.8 \\
3\end{array}$ \\
\hline
\end{tabular}

Tab. 13. Average surface roughness and percentage of improvement in average surface roughness values at different flow pressure. 
Rao, P. S.; Jain, P. K. \& Dwivedi, D. K.: Electro Chemical Honing (Ech) - a New P...

\begin{tabular}{|c|c|c|c|c|c|c|c|c|c|}
\hline \multirow{2}{*}{$\begin{array}{c}\text { SiC } \\
\text { Grit }\end{array}$} & \multicolumn{3}{|c|}{$\begin{array}{c}\text { Top portion of } \\
\text { cylindrical w/p }\end{array}$} & \multicolumn{3}{c|}{$\begin{array}{c}\text { Middle portion of } \\
\text { cylindrical w/p }\end{array}$} & \multicolumn{3}{c|}{$\begin{array}{c}\text { Bottom portion of } \\
\text { cylindrical w/p }\end{array}$} \\
\cline { 2 - 11 } Size & Before & After & PIR $_{\mathrm{a}}$ & Before & After & PIR & Before & After & PIR $_{\mathrm{a}}$ \\
& ECH & ECH & & ECH & ECH & & ECH & ECH & \\
\hline 120 & 4.21 & 1.050 & 75.06 & 4.20 & 1.049 & 75.08 & 4.17 & 0.990 & 76.26 \\
\hline 360 & 4.16 & 0.980 & 76.44 & 4.19 & 0.915 & 78.40 & 4.18 & 0.979 & 76.58 \\
\hline 600 & 4.19 & 0.915 & 78.40 & 4.30 & 0.910 & 78.83 & 4.38 & 0.890 & 79.68 \\
\hline 1200 & 4.55 & 0.854 & 87.23 & 4.45 & 0.710 & 84.04 & 4.89 & 0.950 & 80.57 \\
\hline
\end{tabular}

Tab. 14. Average surface roughness and percentage of improvement in average surface roughness values at different grit size.

\begin{tabular}{|c|c|c|c|c|c|c|c|c|c|}
\hline \multirow{2}{*}{$\begin{array}{l}\text { Current } \\
\text { in A }\end{array}$} & \multicolumn{3}{|c|}{$\begin{array}{l}\text { Top portion of } \\
\text { cylindrical w/p }\end{array}$} & \multicolumn{3}{|c|}{$\begin{array}{l}\text { Middle portion of } \\
\text { cylindrical w/p }\end{array}$} & \multicolumn{3}{|c|}{$\begin{array}{l}\text { Bottom portion of } \\
\text { cylindrical w/p }\end{array}$} \\
\hline & $\begin{array}{c}\text { Before } \\
\text { ECH }\end{array}$ & $\begin{array}{l}\text { After } \\
\text { ECH }\end{array}$ & $\mathrm{PIR}_{\mathrm{a}}$ & $\begin{array}{c}\text { Before } \\
\text { ECH }\end{array}$ & $\begin{array}{l}\text { After } \\
\text { ECH }\end{array}$ & $\mathrm{PIR}_{\mathrm{a}}$ & $\begin{array}{c}\text { Before } \\
\text { ECH }\end{array}$ & $\begin{array}{l}\text { After } \\
\text { ECH }\end{array}$ & $\mathrm{PIR}_{\mathrm{a}}$ \\
\hline 30 & 4.17 & 0.990 & 6.26 & 4.10 & $\overline{940}$ & 77.07 & 4.21 & & 75.06 \\
\hline 40 & & & 8.83 & 4.19 & & 78.40 & 4.18 & & 76.58 \\
\hline 50 & 5.20 & 0.820 & 84.23 & 4.46 & 0.710 & 84.08 & 4.90 & 0.949 & 80.63 \\
\hline 60 & 4.89 & 0.950 & 80.57 & 4.08 & 0.901 & 77.42 & 4.20 & 1.049 & 75.08 \\
\hline
\end{tabular}

Tab. 15. Average surface roughness and percentage of improvement in average surface roughness values at different current.

\begin{tabular}{|c|c|c|c|c|c|c|c|c|c|}
\hline \multirow{2}{*}{$\begin{array}{l}\text { Voltage } \\
\text { In V }\end{array}$} & \multicolumn{3}{|c|}{$\begin{array}{l}\text { Top portion of } \\
\text { cylindrical w/p }\end{array}$} & \multicolumn{3}{|c|}{$\begin{array}{c}\text { Middle portion of } \\
\text { cylindrical w/p }\end{array}$} & \multicolumn{3}{|c|}{$\begin{array}{c}\text { Bottom portion of } \\
\text { cylindrical w/p }\end{array}$} \\
\hline & $\begin{array}{l}\text { Before } \\
\text { ECH }\end{array}$ & $\begin{array}{l}\text { After } \\
\text { ECH }\end{array}$ & $\mathrm{PIR}_{\mathrm{a}}$ & $\begin{array}{l}\text { Before } \\
\text { ECH }\end{array}$ & $\begin{array}{l}\text { After } \\
\text { ECH }\end{array}$ & $\mathrm{PIR}_{\mathrm{a}}$ & $\begin{array}{l}\text { Before } \\
\text { ECH }\end{array}$ & $\begin{array}{l}\text { After } \\
\text { ECH }\end{array}$ & $\mathrm{PIR}_{\mathrm{a}}$ \\
\hline 10 & 4.30 & 0.910 & 78.83 & 4.08 & 0.901 & 77.42 & 4.38 & 0.8 & \\
\hline 20 & 4.45 & 0.710 & 84.04 & 4.54 & 0.855 & 81.17 & 4.55 & 54 & 87.23 \\
\hline 30 & 4.90 & 0.949 & 80.63 & 4.20 & 1.049 & 75.08 & 4.50 & 0.810 & 82.00 \\
\hline 40 & 4.06 & 0.901 & 77.83 & 4.21 & 1.050 & 75.06 & 5.68 & 1.190 & 78.75 \\
\hline
\end{tabular}

Tab. 16. Average surface roughness and percentage of improvement in average surface roughness values at different voltage.

When machining was done at combination of higher levels of input process parameters, some burrs arise on the machined surface. Fig. 19. and Fig. 20. Shows Average surface roughness Histogram data and 2D Average surface roughness Histogram data AFM technique respectively. It is clear from the plots that the surface roughness present in the surface after ECH is significantly reduced by the process. Hence the ECH process is feasible for better material removal and shiny finishing look for giving good aesthetics.

The experimental results reveals thata very good improvement in average surface roughness Ra about $80.63 \%$ at top portion of the Cylindrical work piece, $80.57 \%$ at middle portion of the Cylindrical work piece and $84.08 \%$ at bottom portion of the Cylindrical work piece respectively at 12 minutes of Finishing Time at 0.50 um of inter 
electrode gap as shown in Table 11. Even if an electrolyte flow rate is concerned, from the Table 12 it is evident that, $25 \mathrm{l} / \mathrm{min}$ of electrolyte flow rate gives better surface finish and shows a very good percentage improvement in surface finish about $80.75 \%$ at top portion of the Cylindrical work piece, $82.30 \%$ at middle portion of the Cylindrical work piece and $80.36 \%$ at bottom portion of the Cylindrical work piece respectively and there is considerable decrease in surface roughness with increase in processing time.

Regarding pressure of an electrolyte, it is again evident from the Table 13 that the maximum 1.5 MPa of electrolyte pressure shows a very good percentage improvement in surface finish about $84.04 \%$ at top portion of the Cylindrical work piece, $87.23 \%$ at middle portion of the Cylindrical work piece and $80.57 \%$ at bottom portion of the Cylindrical work piece respectively. Fig.21. shows 3D surface roughness of Ti alloy Ti $6 \mathrm{Al} 4 \mathrm{~V}$ by AFM technique surface finish of ECHed surfaces and again there is considerable decrease in surface roughness with increase in processing time. As per the grit size of $\mathrm{SiC}$ Abrasive is concerned, Table 14 results reveals that better surface finish at maximum 1200 grit size of $\mathrm{SiC}$ and shows a very good percentage improvement in surface finish about $87.23 \%$ at top portion of the Cylindrical work piece, $84.04 \%$ at middle portion of the Cylindrical work piece and $80.57 \%$ at bottom portion of the Cylindrical work piece respectively. Fig.22. shows SEM photographs of electrochemically honed (ECHed) Ti alloy work piece surface (a) before ECH and (b) after $\mathrm{ECH}$.

\subsection{Experimental results and data of EN8 Steel Material}

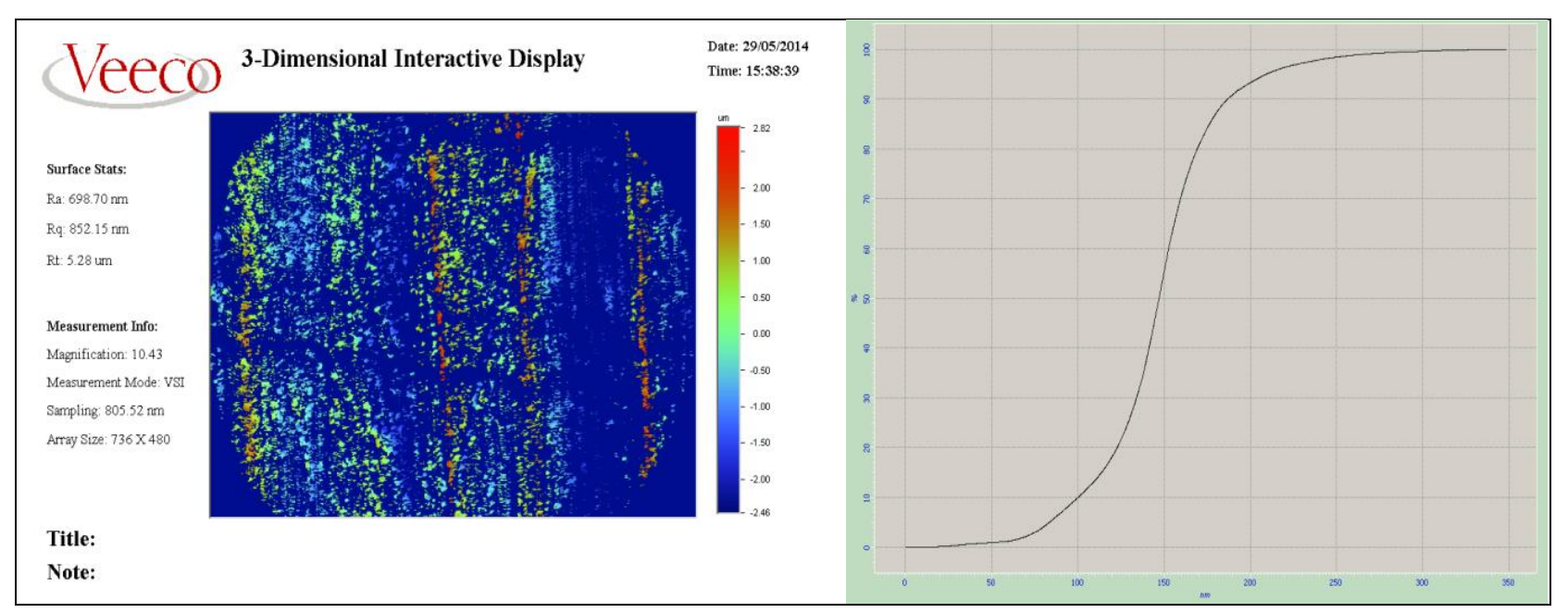

Fig. 16. 3D Average surface roughness data Fig. 17. 2D Bearing ratio data of EN8 alloy by AFM technique 
Rao, P. S.; Jain, P. K. \& Dwivedi, D. K.: Electro Chemical Honing (Ech) - a New P...

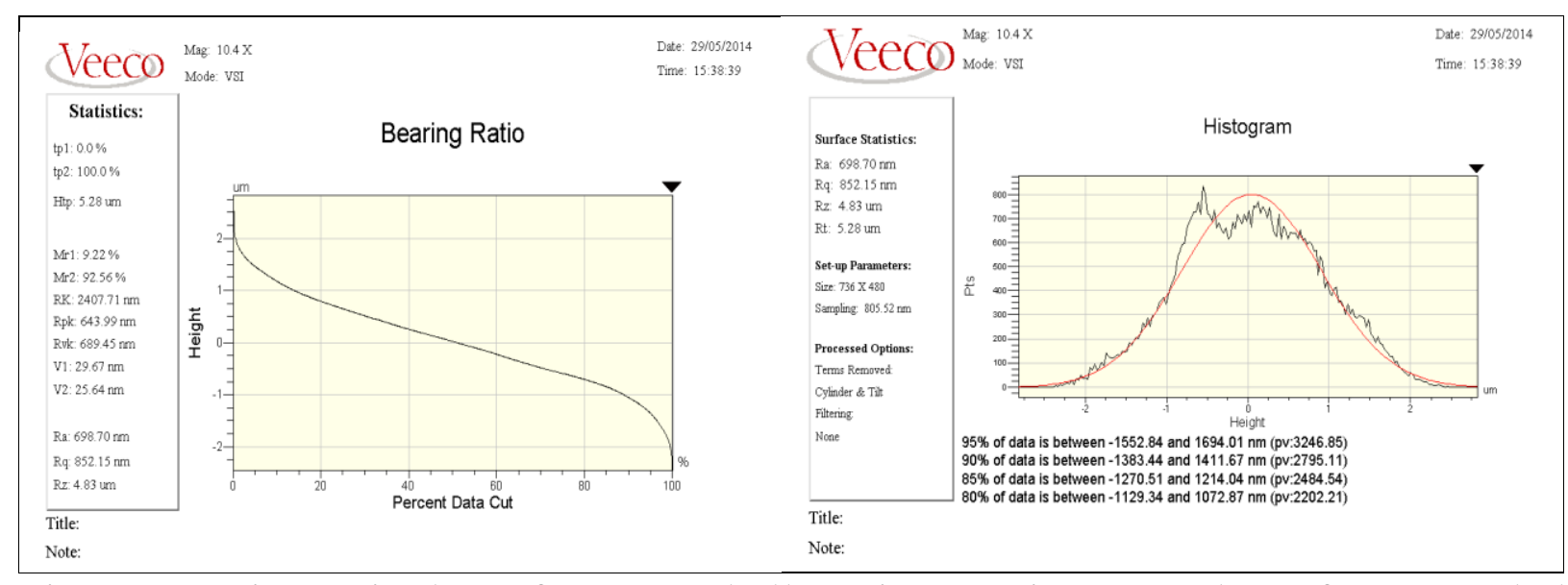

Fig.18. Bearing ratio data of EN8 steel alloy Fig.19. Histogram data of EN8 steel alloy

From the results of current is concerned, Table 15 describes that, 50 amperes of current gives better surface finish and shows a very good percentage improvement in surface finish about $84.23 \%$ at top portion of the Cylindrical work piece, $84.08 \%$ at middle portion of the Cylindrical work piece and $80.63 \%$ at bottom portion of the Cylindrical work piece respectively. From the experimental results, it can be observed that a very good improvement in average surface roughness Ra about $84.04 \%$ at top portion of the Cylindrical work piece, $81.17 \%$ at middle portion of the Cylindrical work piece and $87.23 \%$ at bottom portion of the Cylindrical work piece at 20 volts of voltage as shown in Table 16.

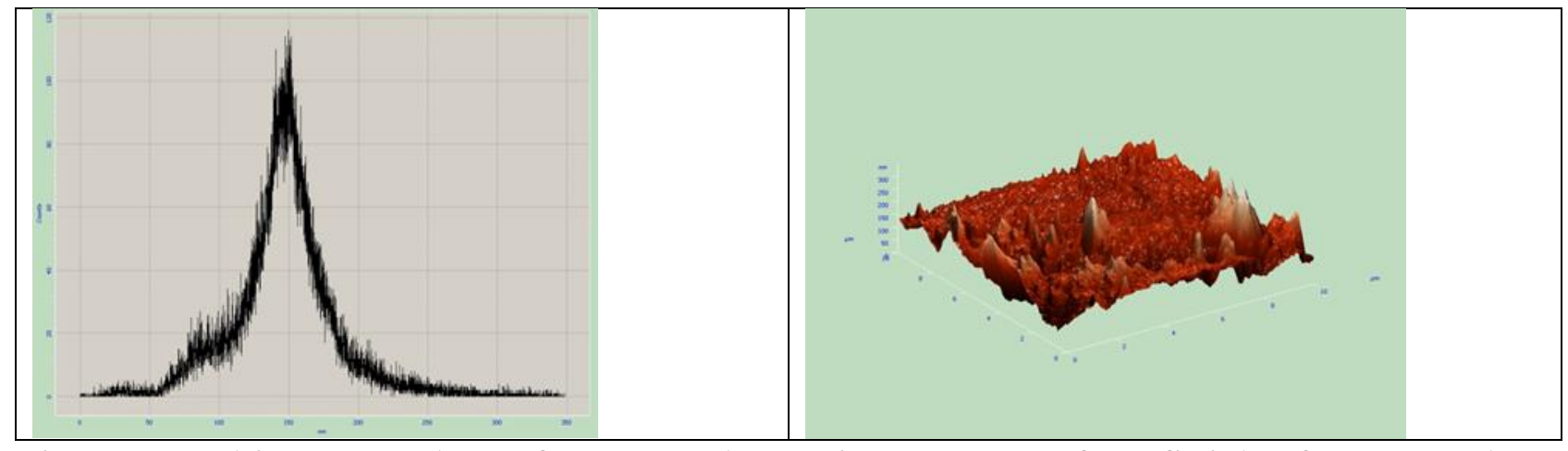

Fig. 20. 2D histogram data of EN8 steel

Fig.21. 3D surface finish of EN8 steel alloy by AFM technique

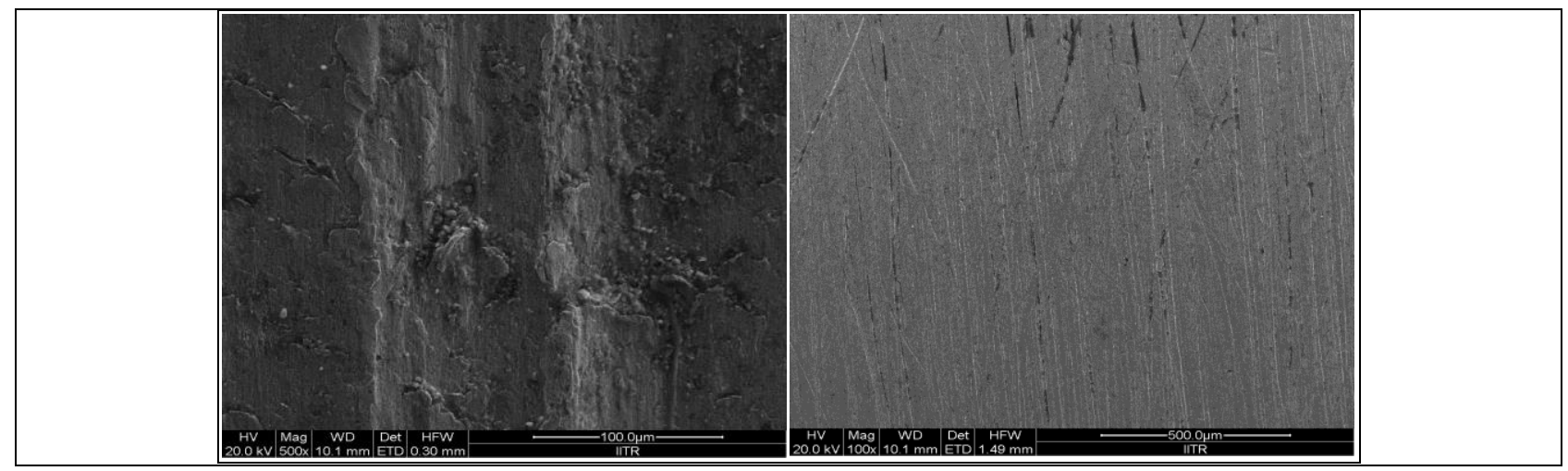

(a)

(b)

Fig.22. SEM photographs of electrochemically honed (ECHed) EN8 steel alloy surface (a) before $\mathrm{ECH}$ and (b) after $\mathrm{ECH}$ 


\section{Conclusions}

The complex interactions of the electrical, chemical and mechanical characteristics of AMPs are still not completely understood and its potential manufacturing capabilities are not completely recognized. Extensive research efforts and continuing advancements in enabling technologies required for improvements in $\mathrm{AMP}$ and further in $\mathrm{ECH}$. It is evident, that the processing time has immense influence on material removal mechanism of the process.

Experimental investigations were carried out to study the effects of important ECH process parameters such as inter electrode gap, flow rate of electrolyte, electrolyte pressure, abrasive type, grit size, current, voltage and finishing time on surface roughness characteristics (i.e. $R_{a}$ ), micro-hardness, surface integrity can be observed. An experimental conclusion can be made based upon the results of experiments obtained by ECH process, 08 minutes as finishing time, $0.50 \mu \mathrm{m}$ of inter electrode gap IEG, $30 \mathrm{lit} / \mathrm{min}$ electrolyte flow rate, $1.0 \mathrm{MPa}$ of electrolyte pressure, 600 grit size of $\mathrm{SiC}$ abrasive, $70 \mathrm{~A}$ of current and $30 \mathrm{~V}$ of voltage were found optimum for precision super finishing of external cylindrical surfaces of Ti alloy material. The results shows that, all the parameters are highly important to achieve the better surface finish and also for better amount of material removal. Similarly, 12 minutes as finishing time, $0.50 \mu \mathrm{m}$ of inter electrode gap IEG, $25 \mathrm{lit} / \mathrm{min}$ electrolyte flow rate, $1.5 \mathrm{MPa}$ of electrolyte pressure, 1200 grit size of $\mathrm{SiC}$ abrasive, $50 \mathrm{~A}$ of current and $20 \mathrm{~V}$ of voltage were found optimum for precision super finishing of external cylindrical surfaces of EN8 Steel material.

In this work, an attempt was made to study the effects of input process parameters like processing time,inter electrode gap IEG, electrolyte flow rate, electrolyte pressure, grit size of $\mathrm{SiC}$ abrasive, current and voltage were found that they play a very significant role in the minimization of roughness. The study illustrates that initially the processing rate is high, but it slows down as the processing time increases. But even with increased processing time, its productivity and mechanical properties are good enough. It is also found, that the process is highly capable of reducing the irregularities on cylinder surfaces. However, like most of the hybrid machining processes, ECH is also in the development phase and therefore, a sustained global research is still required to perform it into other tougher and hardest materials as well as other process parameters.

Further research could consider the study of effect of different parameters and other different electrolyte related parameters etc. Further study is in progress to look into other response parameters like cylindricity, circularity, diameter decrease rate and axis deviation of the cylindrical components for Titanium and EN8 material. However, like most of the hybrid machining processes, $\mathrm{ECH}$ is also in the development phase and therefore, a sustained global research is required to transform it into a matured manufacturing technology and for its successful industrial applications and commercialization.

\section{References}

Bannard, J. (1976). On the electrochemical machining of some titanium alloys in bromide electrolytes, J. of Applied Electrochemistry, Vol. 6, pp. 477-483 
Rao, P. S.; Jain, P. K. \& Dwivedi, D. K.: Electro Chemical Honing (Ech) - a New P...

Benedict, G.F. (1987). Nontraditional Manufacturing Processes, (Marcel Dekker, New York)

Budzynski, A.(1989). Theoretical and experimental research on process of electrochemical honing (ECH).,ISEM-9, Nagoya

Burr, A.E. De and Oliver D.A. (1968). Electrochemical Machining, (Macdonald \& Co. Ltd.)

Chen, C.P. , Liu, j. , Wei, G. C. ,Wan, C. B. and Wan, J. (1981). Electro-chemical honing of gears - A new method of gear finishing, Annals of CIRP, vol 30,103-106.

Das, M.K. , Kaushik, K. , Barman, T.K. , Sahoo, P., (2014). Optimization of Surface Roughness and MRR in Electrochemical Machining of EN31 Tool Steel Using Greytaguchi Approach, Procedia Materials Science, 6, 729-740

Dubey, A.K. (2006). Development of the setup and performance optimization of electrochemical honing process, $P h D$ Thesis, IIT Roorkee

Dubey, A.K. (2008). Experimental investigations on electrochemical honing. Proc. IMechE, Part B: J. Engineering Manufacture, Vol. 222, No. B3, pp. 413-426

El-Hofi, H. (2005). Fundamentals of Machining Processes, McGraw-Hill Book Co., New York

He, F. , Zhang, W. and Nezu, K. (2000). A precision machining of gears (SlowScanning Field Controlled Electrochemical Honing), JSME International Journal Series $C$, 43, No. 2, 486-491

$\mathrm{Lu}, \mathrm{X}$. and Leng, Y. (2005). Electrochemical micromachining of titanium surfaces for biomedical applications, J. of Materials Processing Technology, 169, pp. 173-178

Mandal K. K. (2013). Development of an ANN Model to Predict Surface Roughness During Cryogenic Machining Operation, Int J of Advanced Materials Manufacturing \& Characterization, 3, Issue 1,567-674

Misra, J.P. , Jain, P.K. and Dwivedi, D.K. (2011). Electrochemical honing-A novel technique for gear finishing, DAAAM International Scientific Book, Chapter 29, 365382

Misra, J.P., Jain, P.K. and Sevak, R. (2012). ECH of spur gears-A step towards commercialization, DAAAM International Scientific Book, Chapter 17, 197-212

Misra, J.P. , Jain, P.K. , Dwivedi, D.K. and Mehta, N.K. (2013). Study of time dependent behavior of electro chemical honing $(\mathrm{ECH})$ of bevel gears, 24th DAAAM International symposium on intelligent manufacturing and automation 2013, J. of Procedia Engineering, 64, 1259-1266

Merchant, M.E. (1961) The manufacturing system concept in production engineering research, CIRP Annals, 10, 77-83

Pandey, P.C. and Shan, H.S. (1980). Modern Machining Processes, (Tata McGrawHill Publishing Company, New Delhi)

Rao, P.S. , Jain, P.K. and Dwivedi, D.K.(2014).Electro chemical honing (ECH) of external cylindrical surfaces of titanium alloys, 25th DAAAM International symposium on intelligent manufacturing and automation, J. of Procedia Engineering, 100, 936-945

Rao, P.S. , Jain, P.K. and Dwivedi, D.K. (2015). Precision finishing of external cylindrical surfaces of EN8 steel by electro chemical honing $(\mathrm{ECH})$ process using OFAT technique, 4th International conference on materials processing and characterization, J. of Materials Today Proceedings (under press)

Sun, S., Brandt, M., Daragusch,M.S.,(2009). Characteristics of cutting forces and chip formation in machining of titanium alloys, Int. J. of Machine Tools \& Manufacture, 49, 561-568

Wei G. Q., Wang Z. B.,Chen C. P., (1987). Field Controlled Electrochemical Honing of Gears, Precision Engineering, 9, 218-221 